\title{
Chapter 27 \\ Diaspora Policies, Consular Services and Social Protection for Spanish Citizens Abroad
}

\author{
Pau Palop-García
}

\subsection{Diaspora Policy Infrastructure and Key Policies}

This chapter examines the social protection services offered by Spain to its nationals abroad. Following the framework of this volume, the chapter outlines first the key engagement policies and diaspora infrastructure established by Spain. Secondly, the chapter focuses on five core social protection policies: unemployment, health care, pensions, family-related benefits, and economic hardship. Although the chapter relies mainly on primary sources (international treaties, laws and regulations), secondary sources are used to complement and clarify the findings. The information included in the chapter reflects the policies in force as of January 2019.

\subsubsection{The Spanish Emigrant Community and Its Relations with the Homeland}

Based on the official statistics provided by the Spanish residence registry (Padrón de españoles residentes en el extranjero, PERE), a total of 2,482,808 Spanish citizens were permanently residing abroad at the beginning of $2018 .{ }^{1}$ This number is the result of more than one century of emigration that has led to a diverse diaspora made up by differentiated groups. Among others, the descendants of the Spanish

\footnotetext{
${ }^{1}$ INE (2018). Estadística del Padrón de Españoles Residentes en el Extranjero (PERE) a 1 de enero de 2018. https://www.ine.es/prensa/pere_2018.pdf. Accessed 4 March 2019. This figure is based on voluntary registrations in Spanish consulates.
}

P. Palop-García $(\square)$

GIGA German Institute of Global and Area Studies, Hamburg, Germany

e-mail: pau.palop@giga-hamburg.de 
exiles of the Civil War and early Francoism which have retained Spanish nationality (Pasetti 2017), Spaniards who emigrated mostly to other countries in Europe during the 1950s and 1960s seeking higher standards of living (Kreienbrink 2009; Sánchez Alonso 2010) and new emigrants that moved abroad in the aftermath of the financial crisis of 2008 (Parella and Petroff 2014; Domingo and Blanes 2015). ${ }^{2}$ This great variation regarding the origins and drivers of the Spanish emigration correlates also with the existence of considerable groups of emigrants in both sides of the Atlantic. ${ }^{3}$

This diversity in terms of emigrants' profiles and their respective destination countries has prompted Spain to develop an emigrant policy strategy that aims at addressing the different needs of non-resident Spaniards. This is indeed shown in the ample amalgam of services that Spain offers to its citizens abroad, ranking from pensions to elderly that lack support in their host country, to programs aiming to help Spaniards abroad integrate in the labor market of their country of residence. The next sections of the chapter describe in detail the diaspora infrastructure and the key engagement policies developed by Spain.

\subsubsection{Diaspora Infrastructure}

The core of the Spanish diaspora infrastructure is embedded within two ministerial departments. First, within the Ministry of Foreign Affairs, European Union and Cooperation (Ministerio de Asuntos Exteriores Unión Europea y Cooperación), the Directorate General for Spaniards Abroad and Consular and Migratory Affairs (Dirección General de Españoles en el Exterior y de Asuntos Consulares y Migratorios) is in charge of the protection of Spanish nationals abroad, including the management of emergency situations that involve Spanish emigrants and the supervision of consular services. ${ }^{4}$ Second, within the Ministry of Employment, Migrations and Social Security (Ministerio de Trabajo, Migraciones y Seguridad Social), the State Secretary for Migration (Secretaría de Estado de Migraciones) is

\footnotetext{
${ }^{2}$ This last emigration wave consisted mostly of migrants who naturalised in Spain and returned to their origin countries (mainly in Latin America) and young generations that emigrated looking for better working conditions in other European countries (Parella and Petroff 2014; Domingo and Blanes 2015).

${ }^{3}$ For instance, the five countries hosting the highest number of Spaniards in 2018 were Argentina, France, Venezuela, Germany and Mexico (INE 2018).

${ }^{4}$ Real Decreto 768/2017, de 28 de julio, por el que se desarrolla la estructura orgánica básica del Ministerio de Asuntos Exteriores y de Cooperación y se modifica el Real Decreto 424/2016, de 11 de noviembre, por el que se establece la estructura orgánica básica de los departamentos ministeriales [Royal Decree 768/2017, of 28 July, developing the basic organisational structure of the Ministry of Foreign Affairs and Cooperation and amending Royal Decree 424/2016, of 11 November, establishing the basic organisational structure of the ministerial departments]. 2017. Boletín Oficial del Estado, No 180, p. 70365.
} 
in charge of developing policies on immigration, immigrant integration, and emigration policy. ${ }^{5}$

Spain has an extensive consular network composed of 179 consular missions distributed in 96 countries (including consular sections in Spanish embassies) and honorary consulates. ${ }^{6}$ Interestingly, as opposed to other countries with an extensive consular network (e.g. Germany), Spain does not have a law on consular protection (Faro and Moraru 2010, p. 464), but rather a series of regulations that define the contours of the services that consular missions ought to provide to Spaniards abroad. Honorary consulates are regulated by the Royal Decree 1390/2007. As this Decree explicitly recognizes, honorary consulates are modeled on the Vienna Convention of 1963. Their general role is to assist and act as delegates of the diplomatic official to whom they report. Honorary consulates need explicit authorization from the Consul that they represent to exercise their competences. Their tasks include, but are not limited to, the legalization of signatures on public documents, the facilitation of the registration in the Spanish Register of Nationals Abroad and the processing of applications for passports. ${ }^{7}$

Spain has also created emigrant consultative bodies. The consultation is allocated at two levels: at the consulate level through the Councils of Spanish Residents Abroad (Consejos de Residentes Españoles en el Extranjero) and at a national level with the General Council of Spanish Citizens Abroad (Consejo General de la Ciudadanía Española en el Exterior). The Councils of Spanish Residents Abroad have as their main function to advise the director of the consular mission on issues that concern the Spanish community residing in the consular demarcation. However, the consul does not have to consult the Councils prior to taking his/her decisions. The Councils are made up of 7, 11, or 15 members, depending on the size of the Spanish community residing in the consular demarcation. The members are directly elected for a period of 4 years by Spanish citizens officially registered as residents in the consular demarcation, and meetings are held in assemblies in the consular demarcation. ${ }^{8}$ The General Council of Spanish Citizens Abroad was established by

\footnotetext{
${ }^{5}$ Real Decreto 355/2018, de 6 de junio, por el que se reestructuran los departamentos ministeriales [Royal Decree 355/2018, of 6 June, restructuring ministerial departments]. 2018. Boletín Oficial del Estado, No 138, p. 58722.

${ }^{6}$ Ministry of Foreign Affairs and Cooperation (2018). Embajadas y consulados. http://www.exteriores.gob.es/Portal/es/ServiciosAlCiudadano/Paginas/EmbajadasConsulados.aspx. Accessed 9 May 2018. Spain does not have mobile consulates.

${ }^{7}$ See: Real Decreto 1390/2007, de 29 de octubre, por el que se aprueba el Reglamento de los Agentes Consulares Honorarios de España en el extranjero [Royal Decree 1390/2007, of 29 October, approving the Regulations for Honorary Consular Agents of Spain abroad]. Boletin Oficial del Estado, No 272, p. 46378.

${ }^{8}$ Art. 9, 12 and 13 of Ley 40/2006, de 14 de diciembre, del Estatuto de la ciudadanía española en el exterior [Law 40/2006 of the Statute of Spanish Citizenship Abroad]. 2006. Boletin Oficial del Estado, No 299, p. 44156 and Real Decreto 1960/2009, de 18 de diciembre, por el que se regulan los Consejos de Residentes Españoles en el Extranjero [Royal Decree 1960/2009, of 18 December, regulating the Councils of Spanish Residents Abroad]. 2009. Boletín Oficial del Estado, No 2, p. 137.
} 
Law 40/2006. It is placed at the national level and consults directly with the Government on issues that affect Spanish residents abroad. It can request studies, make proposals and recommendations, and must be informed in advance about legislation that will affect the civil rights, labor rights, social protection, education, and culture of Spanish nationals abroad. However, their recommendations are not legally binding. The Council is composed of one president (appointed by Minister and ratified by the majority of the Council), two vice-presidents (representatives of different offices of the Ministry), one secretary (Director General of Emigration Affairs), and up to 43 Council members elected by the Councils of Spanish Residents Abroad. The Council meets in assembly at least once a year (the president can call for extraordinary meetings) and in specific committees. ${ }^{9}$

Interestingly, most of the mainstream Spanish parties include nationals abroad within their organic structure. The People's Party (Partido Popular) has a representative of emigrants in its executive, the Socialist Party (Partido Socialista Obrero Español) has a Secretary of Emigration, and members of the leftist party PODEMOS that reside abroad constitute a formal territory, with the same representation at the federal level as the members of other Spanish regions. In addition, PODEMOS has a representative of emigrants that participates in the area of Foreign Affairs, Cooperation, and Return (Área de Exteriores, Cooperación y Retorno), which reports to the Secretary of International Affairs (Secretaría Internacional).

At the sub-national level, regional Governments tend to focus on immigration issues, rather than engagement policies. This is reflected also in their infrastructure, since most of them only have administration units dedicated to the integration of immigrants and only some Autonomous Communities (Comunidades Autonónomas) have a specific department for emigrant issues (see, for instance, the Secretary of emigration of the Galician Government or the Directorate General for Emigration and Development Cooperation in Asturias).

\subsubsection{Key Engagement Policies}

The Spanish emigrant policy strategy has been described as horizontal, as there is not a catch-all legal text that regulates all aspects of emigrant policy, but rather a set of laws, royal decrees, and administrative orders enacted over the last 30 years that add up to a quite comprehensive regulation of the relationship between the Spanish state and its nationals abroad (Pasetti 2017). Nevertheless, despite the abundance of regulations, it is still possible to identify the cornerstones of the Spanish diaspora engagement strategy. The Spanish Constitution, for instance, establishes that the state "... shall pay particular attention to safeguarding the economic and social

\footnotetext{
${ }^{9}$ Information presented in this section on the General Council of Spanish Citizens Abroad is based on Art. 11-16 of Real Decreto 230/2008, de 15 de febrero, por el que se regula el Consejo General de la Ciudadanía Española en el Exterior [Royal Decree 230/2008, of 15 February, regulating the General Council of Spanish Citizens Abroad]. 2008. Boletín Oficial del Estado, No 41, p. 8734.
} 
rights of Spanish workers abroad and shall direct its policy towards their return". ${ }^{10}$ This constitutional mandate is then reflected in relevant posterior regulations such as Law 40/2006 of the Statute of Spanish Citizenship Abroad, the Royal Decree 1493/2007 regulating the aid granted to meet the extraordinary needs of Spanish returnees ${ }^{11}$ or Law 2/2014 on State Action and Foreign Service.

Based on Art. 2 of the Royal Decree 3425/2000, Spaniards abroad must register in the Consular Register (Registro de Matrícula Cosular). ${ }^{12}$ Nonetheless, not complying with this obligation does not impair the right to consular protection that corresponds to all Spaniards abroad. To register, it is necessary to visit personally the consular office, show proof of residence abroad, proof of identity and Spanish nationality, fill out a form, and provide a photo. Once the registration has been completed, the applicant loses his/her residence in Spain and officially becomes a resident abroad. Registration as residents abroad limits the access to some social policies in Spain such as unemployment benefits or guaranteed minimum resources. Although registration is mandatory, it is common that Spanish emigrants only register when it becomes necessary for accessing consular services such as the renewal of a passport or voting from abroad in homeland elections. The registration is conducted by the Consular Office in coordination with the National Statistics Institute. ${ }^{13}$ Moreover, Spanish nationals abroad can renew and apply for a Spanish passport. The passport must be requested in person at the consular office. Diplomatic and consular missions are competent to issue passports in coordination with the Ministry of Interior. ${ }^{14}$ However, the National Identification Document (Documento Nacional de Identidad, DNI), the most common identification document used in Spain, can only be renewed or issued in Spain. To do so, Spanish nationals abroad must have a certificate issued by the Consular Civil Registry that shows proof of their residence abroad. With this certificate, the applicant has to travel back to Spain and appear before the National Police Force, the office in charge of issuing the document.

Spanish nationals abroad can vote in national and regional elections (including elections for national upper and lower houses, regional legislative chambers, and

\footnotetext{
${ }^{10}$ Art. 42 Constitución Española [Spanish Constitution]. 1978. Boletín Oficial del Estado, No 311, p. 29313.

${ }^{11}$ Real Decreto 1493/2007, de 12 de noviembre, por el que se aprueban las normas reguladoras de la concesión directa de ayudas destinadas a atender las situaciones de extraordinaria necesidad de los españoles retornados [Royal Decree 1493/2007, of 12 November, approving the rules governing the aid to attend the extraordinary needs of Spanish returnees]. 2007. Boletín Oficial del Estado, No 283, p. 48331 and Law 40/2006.

${ }^{12}$ Art. 2-3. Real Decreto 3425/2000 de 15 de diciembre, sobre inscripción de los españoles en los Registros de Matrícula de las Oficinas Consulares en el extranjero [Royal Decree 3425/2000, of December 15, on the registration of Spaniards in the Consular Registry]. 2000. Boletín Oficial del Estado, No 3, p. 152.

${ }^{13}$ Ministry of Foreign Affairs and Cooperation (2018b). Otros servicios consulares. http://www. exteriores.gob.es/Portal/es/ServiciosAlCiudadano/SiEstasEnElExtranjero/Paginas/ OtrosServiciosConsulares.aspx. Accessed 9 May 2018.

${ }^{14}$ Ministry of Interior (2018). Procedimiento de expedición. Servicios al Ciudadano. http://www. interior.gob.es/web/servicios-al-ciudadano/procedimiento-de-expedicion. Accessed 9 May 2018.
} 
national and regional referendums), as well as European Parliament elections held in Spain. ${ }^{15}$ To be eligible, nationals abroad must be 18 years old and be registered in the electoral roll of external voters. The registration in the electoral roll is automatic (it is done with the registration as a resident abroad). However, nationals abroad must apply each election cycle in order to cast their ballot. This extra bureaucratic step was introduced in 2011 and has fostered many protests from non-resident Spaniards who claimed that this measure is limiting their right to vote. ${ }^{16}$ External voters can cast the ballot in person in consulates, or make use of postal voting. Representation is assimilated, external votes are counted as part of the in-country electoral district where the external voter lived before emigration or in that with which he/she has a biographical connection. Moreover, Spanish nationals abroad can run as candidates if they are included in a list proposed by a party in one of the electoral districts into which Spain (or the given region) is divided.

Overall, Spain does not seem to focus on economic emigrant policies beyond taxation agreements meant to avoid double taxation and a limited return scheme that includes subsidiary provisions to aid returnees in a situation of extraordinary necessity. ${ }^{17}$

Some of the diaspora engagement policies adopted by Spain also fall under the realm of cultural and education policies. ${ }^{18}$ Spain has created the Classes of Spanish Language and Culture (Aulas de Lengua y Cultura Españolas), a program aiming to help the children of Spanish emigrants to maintain and develop their Spanish language skills, as well as to teach the Spanish culture. ${ }^{19}$ The courses are organized by the Ministry of Education, but taught abroad. The curriculum is taught over 10 years, from ages 7-8 to ages 16-17. The Ministry of Education is in charge of deciding in which cities the courses will be offered. Since 1993, the Ministry also has a network of centers abroad that offer primary and secondary studies according to the Spanish

\footnotetext{
${ }^{15}$ For electoral regulations applicable to Spaniards abroad, see: Ley Orgánica 5/1985, de 19 de junio, del Régimen Electoral General [Organic Law 5/1985, of 19 June, on the General Electoral System]. 1985. Boletín Oficial del Estado, No 147, p. 19110.

${ }^{16}$ See, for instance: Marea Granate (2016). Marea Granate envía al Congreso sus propuestas para la reforma exprés de la LOREG. http://mareagranate.org/2016/10/marea-granate-envia-al-congreso-propuestas-la-reforma-expres-la-loreg/. Accessed 9 May 2018

${ }^{17}$ Royal Decree 1493/2007.

${ }^{18}$ The Cervantes Institutes (Institutos Cervantes), created in 1991 to promote the use of Spanish as a second language around the world, do not incorporate within their goals the promotion of Spanish culture among nationals abroad.

${ }^{19}$ Law 40/2006; Orden EDU/3122/2010, de 23 de noviembre, por la que se regulan las enseñanzas complementarias de Lengua y Cultura españolas para alumnos españoles residentes en el exterior y se establece el currículo de las mismas [Order EDU/3122/2010, of 23 November, which regulates the complementary teaching of Spanish Language and Culture for Spanish students living abroad and establishes their curricula]. 2010. Boletín Oficial del Estado, No 292, p. 100227; Real Decreto 1027/1993, de 25 de junio, por el que se regula la acción educativa en el exterior [Royal Decree 1027/1993, of 25 June, regulating educational activities abroad]. 1993. Boletin Oficial del Estado, No 187, p. 23941.
} 
educative curriculum (Pasetti 2017) ${ }^{20}$ Regarding education policies, although there is not a general framework of public-funded scholarships, Spaniards residing in certain countries (France, Germany, Italy, UK, Peru, etc.) can study in the National Distance Education University (UNED), the biggest public university in Spain by number of students, and take their exams abroad. ${ }^{21}$

Furthermore, there is a grant framework that targets Spanish nationals abroad. It consists of six action programs, including two that explicitly aim at assisting associations of emigrants to cover their operating costs, as well as the eventual renovation of their headquarters ${ }^{22}$, and one that aims at funding initiatives aimed at promoting the social and labor integration of young Spaniards living abroad through actions such as language training. ${ }^{23}$

The Order AEX/1059/2002 $2^{24}$ issued by the Minister of Foreign Affairs provides the framework for consular protection and assistance (Faro and Moraru 2010). The framework includes several aid modalities: repatriations, evacuations, subsistence, allowances in cases of extraordinary emergency, allowances for Spaniards incarcerated abroad, allowances for legal aid, and allowances for burial and cremation. With some exceptions, all the aid provided under this framework is reimbursable. It should be noted that the framework does not include financial assistance to facilitate the repatriation of bodies of nationals deceased abroad, only for the burial or cremation in the state where the person died. Nevertheless, according to the website of the Ministry of Foreign Affairs, Spanish consulates do offer logistical assistance in cases of body repatriations (contact with local authorities, information about the process, etc.).

Spanish regions have not developed full-fledged diaspora engagement policies. By the time of writing this chapter, only some, such as Catalonia, Castilla-La

\footnotetext{
${ }^{20}$ There are two types of programs under this scheme: centers that follow the Spanish curriculum and those that mix the Spanish curriculum with the curriculum of the country where they are located. For more information: https://www.mecd.gob.es/servicios-al-ciudadano-mecd/estadisticas/educacion/exterior/accion.html. Accessed 9 May 2018.

${ }^{21}$ UNED (2018).UNED:Facts andData.http://portal.uned.es/portal/page?_pageid=93,24305391\&_ $\mathrm{dad}=$ portal\&_schema=PORTAL. Accessed 9 May 2018.

${ }^{22}$ Orden ESS/1613/2012, de 19 de julio, por la que se establecen las bases reguladoras de la concesión de subvenciones destinadas a los programas de actuación para la ciudadanía española en el exterior y retornados [Order ESS/1613/2012, of 19 July, establishing the regulatory bases for the granting of subsidies for action programmes for Spanish citizens abroad and returnees]. 2012. Boletín Oficial del Estado, No 174, p. 52658.

${ }^{23}$ Orden ESS/1650/2013, de 12 de septiembre, por la que se establecen las bases reguladoras y se convoca para 2013 la concesión de subvenciones destinadas al programa de Jóvenes de la Dirección General de Migraciones [Order ESS/1650/2013, of 12 September, establishing the regulatory bases and the call for the granting of grants for the Youth Programme of the DirectorateGeneral for Migration for 2013]. 2013. Boletín Oficial del Estado, No 221, p. 70157.

${ }^{24}$ Orden AEX/1059/2002, de 25 de abril, de bases reguladoras de las ayudas de protección y asistencia consulares en el extranjero [Order AEX/1059/2002 of the Ministry of Foreign Affairs and Cooperation which establishes the aid for consular protection and assistance of nationals abroad]. 2002. Boletín Oficial del Estado, No 115, p. 17475.
} 
Mancha, and Asturias, have adopted schemes to facilitate the reintegration of returnees. Engagement policies, thus, seem to be relegated to the national level in Spain.

\subsection{Diaspora Policies and Social Protection in Spain}

The Spanish diaspora policy in the area of social protection is not comprehensive. Although Spain grants social protection to emigrants in some of the five core policy areas discussed in this volume (unemployment, health care, pensions, family-related benefits, and economic hardship), this is limited in coverage and scope, when not totally absent (e.g. economic hardship). Emigrant social protection is regulated mostly through the General Social Security $\mathrm{Act}^{25}$, the Statute of Spanish Citizens Abroad and Order AEX/1059/2002 of the Ministry of Foreign Affairs and Cooperation which establishes the aid for consular protection and assistance of nationals abroad. Spain's approach to the issue of emigrant social protection is also shaped by the European Union (EU) framework, bilateral agreements ${ }^{26}$ and the Multilateral Ibero-American Social Security Agreement (Convenio Multilateral Iberoamericano de Seguridad Social) signed by Spain, Portugal and 13 Latin American countries to cover migrant rights regarding pensions, work accidents, illnesses and disabilities due to work-related reasons.

Social protection is generally implemented abroad based on the collaboration of the social security institutions located in Spain and the so-called Departments of Employment and Social Security (Consejerías de Empleo y Seguridad Social). These are offices created by the Ministry of Employment and Social Security in consular demarcations. Their main function is to assist nationals abroad, by providing information and processing their applications for Spanish social benefits or by providing information (but not intervening in the application process) about benefits offered by the host countries. In general, Spain conceives social protection of nationals abroad as residual or subsidiary, meaning that eligibility is conditional upon the lack of access to other benefits provided by the host countries, or situations of extreme and sudden need. Also, in most cases, the benefits granted must be reimbursed by the beneficiaries, especially those linked to repatriation.

\footnotetext{
${ }^{25}$ Real Decreto Legislativo 8/2015, de 30 de octubre, por el que se aprueba el texto refundido de la Ley General de la Seguridad Social [Royal Legislative Decree 8/2015, of 30 October, approving the consolidated text of the General Social Security Act]. Boletín Oficial del Estado, No 261, p. 103291.

${ }^{26}$ Spain has signed bilateral agreements with Andorra, Argentina, Australia, Brazil, Cape Verde, Canada, Chile, China, Colombia, Korea, Ecuador, the United States, Philippines, Japan, Morocco, Mexico, Paraguay, Peru, the Dominican Republic, Russia, Tunisia, Ukraine, Uruguay and Venezuela (24 countries). See: http://www.seg-social.es/wps/portal/wss/internet/InformacionUtil/ 32078/32253. Accessed 31 May 2019.
} 


\subsubsection{Unemployment}

Unemployment benefits are regulated by the General Social Security Act. There are two levels of unemployment protection: (1) the contributory level providing cash benefits that compensate for the job loss, suspension of contract or reduction of working hours and; (2) the assistance level guaranteeing protection to certain unemployed workers that are not eligible for contributory benefits. To access either of the two levels, residence in Spain is required. However, there are some exceptions for people that receive unemployment benefits and decide to transfer their residence abroad. In the case of transfer abroad for less than 12 months for the purpose of seeking or carrying out work, for participating in international cooperation missions, or to engage in professional development activities, the benefits are suspended and can be resumed upon return. If the transfer is for more than 12 months, the benefits are terminated and cannot be resumed upon return. Following EU regulations, unemployment benefits can also be exported for 3 months (with a possibility of extending them for another 3 months) only in case of transfer to a Member State of the EU, the European Economic Area (EEA), or Switzerland. In this case, the beneficiary must show proof of being registered in the employment services of the host country ${ }^{27}$ All bureaucratic procedures regarding unemployment benefits are managed directly by the Spanish Public Employment Services; consulates do not intervene in any instance. Furthermore, the Spanish Public Employment Services do not offer any kind of pre-departure training for prospective emigrant workers.

The Departments of Employment and Social Security, regulated by Royal Decree 1052/2015, are specialized technical bodies attached to the diplomatic missions. ${ }^{28}$ They act according to the goals and principles set out by the Spanish external strategy (Acción Exterior del Estado) regarding employment, labor relations, social security, and migration and under the lead of the Ministry of Employment and Social Security ${ }^{29}$ They have three main roles. First, they represent the Ministry of Employment and Social Security abroad and advise the diplomatic missions on issues that fall under their competences. Second, they act as the information point

\footnotetext{
${ }^{27}$ Public Service of Public Employment (2018). I am moving abroad (Me traslado al extranjero). https://www.sepe.es/contenidos/personas/prestaciones/estoy_cobrando_paro/me_traslado_al_ extranjero.html. Accessed 4 March 2019.

${ }^{28}$ See: Real Decreto 1052/2015, de 20 de noviembre, por el que se establece la estructura de las Consejerías de Empleo y Seguridad Social en el exterior y se regula su organización, funciones y provisión de puestos de trabajo [Royal Decree 1052/2015, of 20 November, establishing the structure of the Departments of Employment and Social Security abroad and regulating their organisation, functions and the provision of positions]. 2015. Boletín Oficial del Estado, No 279, p. 109757.

${ }^{29}$ In 2018, there were Departments of Employment and Social Security in: Andorra, Argentina, Austria, Belgium, Bolivia, Brazil, Canada, Chile, Colombia, Costa Rica, Cuba, Denmark, the Dominican Republic, Ecuador, El Salvador, Estonia, Finland, France, Germany, Greece, Guatemala, Honduras, Ireland, Italy, Latvia, Liechtenstein, Lithuania, Luxemburg, Mexico, Morocco, the Netherlands, Nicaragua, Norway, Romania, Panama, Paraguay, Peru, Poland, Portugal, Senegal, Sweden, Switzerland, Tunisia, the United Kingdom, the United States, Uruguay, and Venezuela.
} 
for nationals abroad regarding employment and social security issues. Third, they collaborate with the Ministry of Foreign Affairs and Cooperation and the Ministry of Interior to assist nationals abroad to: (1) facilitate their access to the labor market in the host country and facilitate their return; (2) strengthen the relation with emigrant associations; (3) manage the assistance pensions and health care for emigrants; (4) participate in the processing of benefits included in the Spanish Social Security scheme; (5) inform and process the applications for the programs that target emigrants provided by Ministry of Employment and Social Security and the Institute of Elderly and Social Services (Instituto de Mayores y Servicios Sociales, IMSERSO) and; (6) participate in other programs of grants funded by the Ministry in which they may be competent. In their role as information points, several Departments of Employment and Social Security have developed "employment websites" ("Webs de empleo") to offer information on how to find employment and how to access unemployment benefits in host countries. These websites, however, at the time of writing this chapter, do not cover all countries with diplomatic missions. ${ }^{30}$ Finally, neither the consular mission, nor the Departments of Employment and Social Security offer repatriation services for unemployed nationals abroad.

To help emigrants find a job or professional training abroad, the Ministry of Employment and Social Security provides grants to companies and NGOs (based abroad or in Spain). Such grants aim to facilitate access to the labor market to young Spaniards living abroad through professional training and language courses or facilitate returnees' participation in entrepreneurship projects located in Spain. ${ }^{31}$

\subsubsection{Health Care}

Article 17 of Law 40/2006, the Statute of Spanish Citizenship Abroad regulates the right to health care of Spanish nationals abroad. It establishes that nationals abroad must have access to health benefits equivalent to those granted by the Spanish National Health System. Article 17, however, also prioritizes the elderly and dependents. Furthermore, Article 19 establishes that the Spanish General Administration (Administración General del Estado) shall guarantee the right to receive benefits to Spaniards abroad who, having reached the age of 65 or being incapacitated to work, are in a situation of need due to insufficient income to cover their basic needs. This article is further regulated through Royal Decree $8 / 2008,{ }^{32}$ which establishes that

\footnotetext{
${ }^{30}$ List of countries with employment websites: Argentina, Austria, Belgium, Brazil, Chile, Denmark, France, Germany, the Netherlands, Peru, Sweden, Switzerland, the United Kingdom, and the United States.

${ }^{31}$ Order ESS/1650/2013.

${ }^{32}$ Art. 21 Real Decreto 8/2008, de 11 de enero, por el que se regula la prestación por razón de necesidad a favor de los españoles residentes en el exterior y retornados [Royal Decree 8/2008, of 11 January, which regulates the provision of benefits for reasons of necessity in favour of Spaniards living abroad and returnees]. 2008. Boletín Oficial del Estado, No 21, p. 4601.
} 
people that fall under the aforementioned categories are entitled, among other benefits, to health benefits if they lack health care coverage in the country of residence or benefits granted by the host country are considered insufficient. The access to these benefits is managed by the Departments of Employment and Social Security or the diplomatic missions in cooperation with the Secretary of Immigration and Emigration of the Ministry of Employment and Social Security.

Moreover, article 26 of Royal Decree 8/2008 also establishes that Spanish returnees and pensioners of Spanish origin residing abroad that are temporarily displaced to the Spanish territory are entitled to health care as long as, in accordance with the provisions of the Spanish regulations, those of their host country (or the international social security regulations or agreements established for this purpose), health care is not provided. The recognition of health care for these cases corresponds to the Spanish National Institute of Social Security; however, consulates also play a role in the process of recognition, since they are in charge of issuing some of the documentation required (e.g. proof of residence abroad).

Beyond the coverage for returnees and pensioners, Royal Decree 16/2012 establishes that employees of Spanish origin residing in states other than EU/EEA Member States or Switzerland who temporarily move to Spain are entitled to health care in Spain at public expense through the Spanish National Health System. ${ }^{33}$

Article 19 of Royal Decree 8/2008 regulates invalidity benefits granted in article 19 of Law 40/2006. These benefits are only granted when the beneficiaries suffer from physical or psychological disabilities, whether congenital or not, which are expected to be permanent and which disqualify them from any profession or trade. Furthermore, benefits are granted only when there is not a similar benefit offered by host country administrations or if the beneficiary is not eligible for such benefits in the country of residence. Benefits consist of economic aid, calculated based on the living costs of the country of residence of the beneficiary.

Finally, the "Employment websites" developed by the Ministry of Employment and Social Security and the Departments of Employment and Social Security offer information on how to access health care and invalidity benefits provided by host countries.

\footnotetext{
${ }^{33}$ First additional disposition Real Decreto-ley 16/2012, de 20 de abril, de medidas urgentes para garantizar la sostenibilidad del Sistema Nacional de Salud y mejorar la calidad y seguridad de sus prestaciones [Royal Decree-Law 16/2012 of 20 April 2012 on urgent measures to ensure the sustainability of the National Health System and improve the quality and safety of its services]. 2012. Boletín Oficial del Estado, No 98, p. 31278. However, the entitlement is only activated when they are not covered by other health care scheme in accordance with the provisions of the Spanish social security, the provisions of the state of origin or international rules or conventions on social security established for this purpose.
} 


\subsubsection{Pensions}

Spanish nationals abroad can access Spanish pensions through two main routes. The first one is the general route that applies to all Spanish nationals and is regulated by the General Social Security Act. This pension scheme does not require residence in Spain to receive the benefits; only compliance with the general requisites (i.e. a minimum number of years of contribution to the social security system) is necessary. Pensioners that access a pension through this route and decide to move abroad must send the office in charge of managing pensions in Spain a life certificate issued by their consulate on a yearly basis. ${ }^{34}$ The second route is established by Law 40/2006 and regulated by Royal Decree 8/2008. This route grants a right to a pension to Spanish nationals living abroad that have reached the age of 65 and find themselves in a situation of need. To be eligible, beneficiaries must demonstrate that they are in a situation of need, namely that they lack economic resources, are ineligible for benefits in the host country, or that the benefits offered by the receiving country are precarious. ${ }^{35}$

Additionally, within the framework of the Multilateral Ibero-American Social Security Agreement, Spaniards abroad can make their periods of contributions to the Spanish pension system count in the other 14 signatory countries, which include 13 Latin American states. This mechanism to export contributions made to the Spanish pension system is also included in other bilateral agreements on social security signed by Spain, such as the one with Andorra ${ }^{36}$ or Australia. ${ }^{37}$

The Ministry of Employment and Social Security has also developed websites to offer information on how to find employment in some countries. These websites also include the access to social security (including pensions) in the host country and in Spain.

\footnotetext{
${ }^{34}$ Ministry of Labor, Migrations and Social Security (2018). Proof of life [Fé de vida]. http://www. mitramiss.gob.es/es/mundo/consejerias/eeuu/preguntas/contenidos/FeVida.htm. Accessed 4 March 2019.

${ }^{35}$ Based on the last official statistics, as for 2013 , there were 19,893 beneficiaries of this scheme that received an average monthly pension of $164.70 €$. See: Portal of Spanish Citizenship Abroad (2019). Estadísticas y Gráficos. http://www.ciudadaniaexterior.mitramiss.gob.es/es/estadisticas/ index.htm. Accessed 31 May 2019.

${ }^{36}$ Convenio de seguridad social entre el Reino de España y el Principado de Andorra, de 9 de noviembre de 2001 [Social security agreement between the Kingdom of Spain and the Principality of Andorra of November 9, 2001]. 2001. Boletín Oficial del Estado, No 290.

${ }^{37}$ Convenio entre España y Australia sobre Seguridad Social, de 31 de enero de 2002 [Agreement between Spain and Australia on Social Security, of January 31, 2002]. Boletín Oficial del Estado, No 303.
} 


\subsubsection{Family-Related Benefits}

Spanish nationals abroad can obtain a birth certificate from home country authorities for their children born abroad. This is regulated by Law 20/2011 on the Civil Registry. ${ }^{38}$ Furthermore, article 24 establishes that the consular offices can also register the vital records relating to Spaniards residing in their consular district (which include the register of births) and issue certifications of the register entries.

Family benefits are regulated by the General Social Security Act approved by Legislative Royal Decree No. 8/2015 of 30 October 2015. Birth grants are only given in the context of large families, single-parent families, mothers with disabilities, and multiple birth/adoption. Beyond other requisites related to the family income, legal residence in Spain is established as a condition for eligibility. Thus, Spanish nationals abroad cannot access this benefit.

The General Social Security Act also regulates a benefit that aims at covering the cost of raising a child. However, this benefit is restricted to children that suffer from a disability to a degree of $65 \%$ or more and, as for birth grants, residence in Spain is a condition for eligibility. Nationals abroad cannot access maternity or paternity leave, since this is restricted to beneficiaries that are registered in the General Social Security System (Régimen General de la Seguridad Social), which usually implies being employed and a resident in Spain.

In some cases, the "Employment websites" developed by the Ministry of Employment and Social Security also offer information on how to access family benefits in the host countries.

\subsubsection{Economic Hardship}

Spain has two main schemes for guaranteed minimum resources. The first one is the active insertion income program (Renta Básica de Inserción), which is administered by the central Government through the Ministry of Employment and Social Security. This program grants a specific aid aimed at long-term unemployed who are not eligible for general unemployment benefits. Spanish nationals abroad do not have access to this scheme, since being overseas is cause of suspension of the right. ${ }^{39}$ The second scheme is regulated and managed by the regions. Although the conditions and characteristics of this benefit differ significantly across Autonomous Communities, residence is a common condition to be eligible. For instance, in

\footnotetext{
${ }^{38}$ Ley 20/2011, de 21 de julio, del Registro Civil [Law 20/2011, of 21 July, on the Civil Registry]. 2011. Boletín Oficial del Estado, No 175, p. 81468.

${ }^{39}$ Art. 2 Real Decreto 1369/2006, de 24 de noviembre, por el que se regula el programa de renta activa de inserción para desempleados con especiales necesidades económicas y dificultad para encontrar empleo [Royal Decree 1369/2006, of 24 November, regulating the active insertion income programme for unemployed people with special economic needs and difficulty in finding employment]. 2006. Boletín Oficial del Estado, No 290, p. 42716.
} 
Andalusia, article 7 of Decree-Law 3/2017 establishes that residence is a condition for accessing the guaranteed minimum income. ${ }^{40}$ The same applies for the schemes offered by the Balearic Islands ${ }^{41}$ or Madrid. ${ }^{42}$

Order AEX/1059/2002, issued by the Ministry of Foreign Affairs and Cooperation, regulates the aid for consular protection and assistance abroad. This aid includes an extraordinary individual support for assisting Spanish nationals abroad in concrete situations of need, as well as the total or partial coverage of the expenses derived from repatriation. The aid in both cases, extraordinary need and repatriation, is non-recurrent and must be reimbursed. The Order also establishes that Spaniards residing abroad that are above 65 years old or minors have the right to a subsistence allowance in case of economic hardship. The benefits can be recurrent or a onetime payment. Also, depending on the situation, there could be the obligation to reimburse.

Consulates do not have any obligation to assist nationals in their dealing with host country authorities regarding a guaranteed minimum resource scheme. However, the "Employment websites" created by the Ministry of Employment and Social Security offer information about the services that the host countries offer to Spanish residents.

\subsection{Conclusions}

Diaspora engagement policies in Spain have developed incrementally over the years. This is reflected in a disperse regulation, comprising several legal texts on different themes and of different rank (e.g. Constitution, Organic Laws, administrative orders) and an ample diaspora infrastructure formed by administrations with different rank and embedded across different ministerial departments. Nevertheless, the analysis shows that diaspora engagement policies are developed and managed through two main departments: the Secretary of Migrations dependent on the Ministry of Employment, Migrations and Social Security and the Directorate General for Spaniards Abroad and for Consular and Migratory Affairs of the Ministry of Foreign Affairs, European Union and Cooperation.

The diaspora engagement policies developed by Spain focus on specific dimensions. First, the findings reveal that Spanish emigrants enjoy a high degree of political inclusion. They can participate in regional and national elections, as well as in

\footnotetext{
${ }^{40}$ Decreto-Ley 3/2017, de 19 de diciembre, por el que se regula la Renta Mínima de Inserción Social en Andalucía [Decree-Law 3/2017, of 19 December, regulating the Minimum Income for Social Integration in Andalusia]. 2017. BOJA, No 245, p. 11.

${ }^{41}$ Art. 6 Ley 5/2016, de 13 de abril, de la renta social garantizada [Law 5/2016, of 13 April, on Guaranteed Social Income]. 2016. Boletín Oficial del Estado, No 105, p. 29410.

${ }^{42}$ Art. 6 Ley 15/2001, de 27 de diciembre, de Renta Mínima de Inserción en la Comunidad de Madrid [Law 15/2001, of 27 December, on the Minimum Insertion Income in the Community of Madrid]. 2001. BOCM, No 310.
} 
consultative bodies that operate at the national, as well as at the consular level. Political participation, however, has been restricted since 2011 due to changes in the electoral rules for external voting that make voting from abroad more difficult and has led to a significant decline in turnout. Second, Spain's policies tend to focus on emigrants' return and their re-integration in Spain. This is indeed reflected in the regulation of benefits for returnees, which range from the inclusion of return as a priority in the Constitution to the creation of social benefits for returnees in a situation of need. Finally, Spain dedicates a great amount of resources to education and cultural programs abroad, which materializes in the creation of Spanish schools abroad. Remittances and other economic policies do not seem to be salient in Spain during the period analyzed.

Spain also grants social benefits to non-resident citizens, although it does not have a comprehensive scheme of social protection abroad. As shown in this chapter, the social protection of Spanish nationals abroad focuses on assistance in situations of need in which host institutions do not intervene. For instance, only residents in Spain are eligible for unemployment benefits and moving abroad is (with some exceptions) grounds for suspension of the right. Health care coverage of nationals abroad is also limited to those returning to Spain, as long as they are not covered by any other scheme provided by their host country. Residence in Spain is also a hard requisite to be eligible for family benefits as well as guaranteed minimum resources schemes. Pensioners, however, can live in Spain or move abroad if they provide a yearly proof of life. In addition, Spain has developed a pension scheme that targets nationals abroad that have reached the age of 65 years and do not have access to pension benefits offered by their country of residence or by Spain through the standard pathways to pension included in the Spanish social security regulations. Finally, Spain has also regulated the aid of nationals abroad in situation of need. These benefits must be generally reimbursed and can cover health expenses or repatriation.

Acknowledgments This chapter is part of the project "Migration and Transnational Social Protection in (Post)Crisis Europe (MiTSoPro)" that has received funding from the European Research Council (ERC) under the European Union's Horizon 2020 research and innovation programme (Grant agreement No. 680014). In addition to this chapter, readers can find a series of indicators comparing national social protection and diaspora policies across 40 countries on the following website: http://labos.ulg.ac.be/socialprotection/.

\section{References}

Domingo, A., \& Blanes, A. (2015). Inmigración y emigración en España: Estado de la cuestión y perspectivas de futuro. In Anuario de la Inmigración en España 2014 (pp. 92-122). Barcelona: CIDOB.

Faro, S., \& Moraru, M. (2010). Consular and diplomatic protection: Legal framework in the EU member states. SSRN Electronic Journal. https://doi.org/10.2139/ssrn.1998833. 
Kreienbrink, A. (2009). La política de emigracsión a través de la historia del IEE. In Historia del Instituto Español de Emigración. La política migratoria exterior de España y el IEE del franquismo a la transición.

Parella, S., \& Petroff, A. (2014). Migración de retorno en España: salidas de inmigrantes y programas de retorno en un contexto de crisis. In Inmigración y Emigración: mitos y realidades (pp. 62-89). Barcelona: CIDOB.

Pasetti, F. (2017). Living in the past, leaving in the present: Emigration and diaspora policies in Spain. In Emigration and diaspora policies in the age of mobility. http://cadmus.eui.eu// handle/1814/47488. Accessed 9 May 2018.

Sánchez Alonso, B. S. (2010). El final del ciclo emigratorio español: Desideratum., Historia y Política, 23, 135-162. https://recyt.fecyt.es/index.php/Hyp/article/view/44426. Accessed 1 March 2019.

Open Access This chapter is licensed under the terms of the Creative Commons Attribution 4.0 International License (http://creativecommons.org/licenses/by/4.0/), which permits use, sharing, adaptation, distribution and reproduction in any medium or format, as long as you give appropriate credit to the original author(s) and the source, provide a link to the Creative Commons license and indicate if changes were made.

The images or other third party material in this chapter are included in the chapter's Creative Commons license, unless indicated otherwise in a credit line to the material. If material is not included in the chapter's Creative Commons license and your intended use is not permitted by statutory regulation or exceeds the permitted use, you will need to obtain permission directly from the copyright holder. 